\title{
Correction to: Short-term outcome associated with disease severity and electrolyte abnormalities among critically ill children with acute kidney injury
}

Osama Y. Safdar ${ }^{1 *}$, Khalid A. Alhasan ${ }^{3}$, Mohamed A. Shalaby ${ }^{1}$, Norah Khathlan², Suleman A. Al Rezgan ${ }^{4}$, Amr S. Albanna ${ }^{5}$ and Jameela A. Kari ${ }^{1}$

Correction to: BMC Nephrology (2019) 20:89. https://doi.org/10.1186/s12882-019-1278-1

Following publication of the original article [1], we have been notified that there is a typo in the name of the first author.

Incorrect: Osama Y Safder.

Correct: Osama Y Safdar.

\section{Author details}

'Pediatric Nephrology Center of Excellence, Pediatric Department, Faculty of Medicine, King Abdulaziz University, PO Box 80215, Jeddah 21589, Kingdom of Saudi Arabia. ${ }^{2}$ Pediatric Intensive Care Unit, Department of Pediatrics, King Abdulaziz University, Jeddah, Kingdom of Saudi Arabia. ${ }^{3}$ Pediatrics

Department, College of Medicine, King Saud University, Riyadh, Kingdom of Saudi Arabia. ${ }^{4}$ King Fahad Armed Forced Hospital, Jeddah, Kingdom of Saudi Arabia. ${ }^{5}$ King Abdullah International Medical Research Center, King Saud Bin Abdulaziz University for Health Sciences, Jeddah, Kingdom of Saudi Arabia.

Published online: 16 April 2020

\section{Reference}

1. Safder et al. BMC Nephrology (2019) 20:89 https:/doi.org/10.1186/s12882-019-1278-1.

The original article can be found online at https://doi.org/10.1186/s12882019-1278-1

* Correspondence: safderosama@hotmail.com

${ }^{1}$ Pediatric Nephrology Center of Excellence, Pediatric Department, Faculty of Medicine, King Abdulaziz University, PO Box 80215, Jeddah 21589, Kingdom of Saudi Arabia

Full list of author information is available at the end of the article

(c) The Author(s). 2020 Open Access This article is licensed under a Creative Commons Attribution 4.0 International License, which permits use, sharing, adaptation, distribution and reproduction in any medium or format, as long as you give appropriate credit to the original author(s) and the source, provide a link to the Creative Commons licence, and indicate if changes were made. The images or other third party material in this article are included in the article's Creative Commons licence, unless indicated otherwise in a credit line to the material. If material is not included in the article's Creative Commons licence and your intended use is not permitted by statutory regulation or exceeds the permitted use, you will need to obtain permission directly from the copyright holder. To view a copy of this licence, visit http://creativecommons.org/licenses/by/4.0/ The Creative Commons Public Domain Dedication waiver (http://creativecommons.org/publicdomain/zero/1.0/) applies to the data made available in this article, unless otherwise stated in a credit line to the data. 